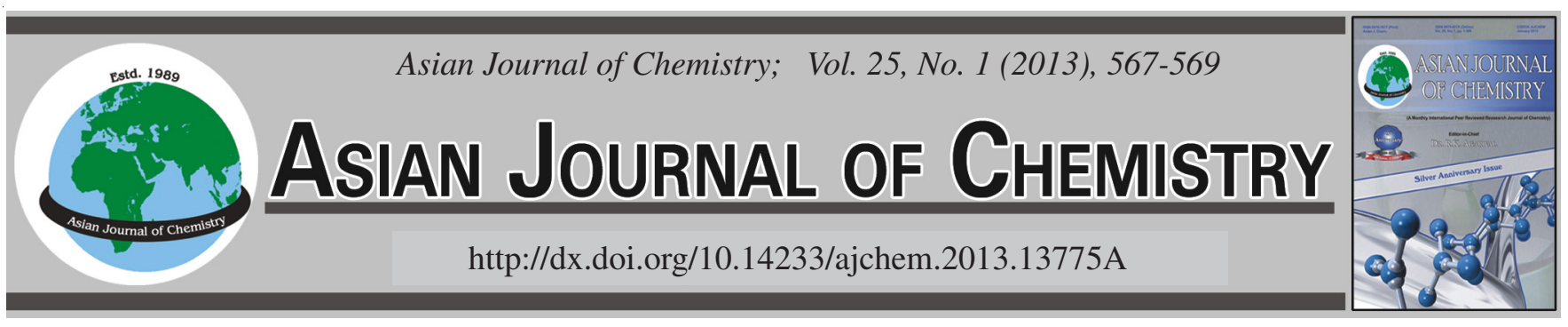

\title{
Study of Chromogenic Reaction of $p$-Acetylchlorophosphonazo with Lead(II)
}

\author{
Jing-Mei Li, Qing-Zhou Zhai ${ }^{*}$ and Ying-Lai Li
}

Research Center for Nanotechnology, Changchun University of Science and Technology, 7186 Weixing Road, Changchun 130022, Jilin Province, P.R. China

*Corresponding author: Fax: +86 431 85383815; Tel: +431 85583118; E-mail: zhaiqingzhou@163.com, zhaiqingzhou@hotmail.com

Key Words: $p$-Acetylchlorophosphonazo, Lead, Spectrophotometry.

\section{INTRODUCTION}

Lead is an element, which the human body does not need. Lead is a stable, non-degradable pollutant that can be accumulated in the environment for a long period of time. If a person keeps in touch with microamount lead for a long time, the accumulated lead can obstruct the forming of blood cells and lead to mental decline, the turndown of study and work. People will show the symptoms of chronic poisoning like psychonosema, nightmare, insomnia and headache accumulated to a certain extent; severe people will show the symptoms of acratia, inappetency, nausea, abdominal distension, bellyache or diarrhoea, etc., Lead can also enter into the brain tissue by blood to injure cerebellum and cerebral cortex considered and interfere metabolic activity to cause the lack of nutrient substance and oxygen supply and then lead to swelling of the cerebellar cortex cells within the capillaries to develop diffuse brain injury ${ }^{1}$. The common methods to measure lead are EDTA titration $^{2}$, anodic stripping voltammetry ${ }^{3}$, flame atomic absorption spectrometry ${ }^{4}$, graphite furnace atomic absorption spectrometry $^{5}$, ICP-AES ${ }^{6}$, dithizone spectrophotometry ${ }^{2}$ and so on. Spectrophotometry can be used to measure lead, particularly that azo reagents are used as chromogenic reagents is paied lots of attention ${ }^{7-9}$. The molecular formula of $p$-acetylchlorophosphonazo ${ }^{10}$ is $\mathrm{C}_{24} \mathrm{H}_{18} \mathrm{~N}_{4} \mathrm{O}_{12} \mathrm{PS}_{2} \mathrm{Cl}$ and its structural formula is shown in Fig. 1.

From Fig. 1 we can see that the aromatic in CPApA contains many $\mathrm{N}, \mathrm{O}$ ligands respectively and the reagent has a strong complexing ability, forming water-soluble complexes with metal irons. It has been used for the spectrophotometric determination of rare earth ${ }^{10}$. It is found in present study that in $\mathrm{CH}_{3} \mathrm{COOH}-\mathrm{CH}_{3} \mathrm{COONa}$ buffer medium at $\mathrm{pH}=3.52$, the reaction of $\mathrm{Pb}^{2+}$ and $\mathrm{CPA} p \mathrm{~A}$ formed a blue complex, which established a new method for the determination of lead. The method is characterized by high sensitivity, simple operation and low analysis cost. Good results were obtained when it was applied to the determination of lead in potato samples.<smiles>CC(=O)c1ccc(N=Nc2c(S(=O)(=O)O)cc3cc(S(=O)(=O)O)c(N=Nc4ccc(Cl)cc4P(=O)([O-])O)c(O)c3c2O)cc1</smiles>

Fig. 1. Molecular structure of CPApA

\section{EXPERIMENTAL}

p-Acetylchlorophosphonazo (CPApA, Shanghai Changke Research Institute of Reagents) $0.0068 \mathrm{~g} \mathrm{CPApA}$ was dissolved in $100 \mathrm{~mL}$ of water and $1 \times 10^{-4} \mathrm{~mol} \mathrm{~L}^{-1}$ of CPApA solution was obtained. $\mathrm{Pb}^{2+}$ standard solution: $0.1599 \mathrm{~g} \mathrm{~Pb}\left(\mathrm{NO}_{3}\right)_{2}$ was accurately weighed and dissolved in distilled water. After $1 \mathrm{~mL}$ of concentrated $\mathrm{HNO}_{3}$ was added, the solution was diluted to be $100 \mathrm{~mL} .1 \mathrm{mg} \mathrm{mL}^{-1}$ of $\mathrm{Pb}^{2+}$ stock solution was obtained and the working solution, $10 \mu \mathrm{g} \mathrm{mL} \mathrm{mL}^{-1}$, was obtained by suitable dilution. $\mathrm{pH} 3.52 \mathrm{CH}_{3} \mathrm{COOH}-\mathrm{CH}_{3} \mathrm{COONa}$ buffer solution : 0.1 mol L $\mathrm{L}^{-1}$ acetic acid and $0.1 \mathrm{~mol} \mathrm{~L}^{-1}$ sodium acetate solution was mixed using the ratio of 1:16 (v/v). Without special illustration, the reagents used in the experiment were of analytical purity and the water was distilled water. 
A 722S spectrophotometer (Shanghai Lingguang Technology Co. Ltd., China) with $1 \mathrm{~cm}$ cells was used for absorbance measurement.

Two $10 \mathrm{~mL}$ volumetric flasks were taken. To one $3 \mathrm{~mL}$ of $10 \mu \mathrm{g} \mathrm{mL} \mathrm{mb}^{-1} \mathrm{~Pb}^{2+}$ solution was added and to the other $\mathrm{Pb}^{2+}$ solution was not added. (blank solution). Then, $4 \mathrm{~mL}$ of $1.0 \times$ $10^{-4} \mathrm{~mol} \mathrm{~L}^{-1}$ of CPApA solution was added to the two flasks in turn, $1.0 \mathrm{~mL}$ of $\mathrm{pH} 3.52 \mathrm{CH}_{3} \mathrm{COOH}-\mathrm{CH}_{3} \mathrm{COONa}$ buffer solution, respectively. The solutions were diluted to the mark with distilled water and shaken well. After $10 \mathrm{~min}$, absorbance was measured at $606 \mathrm{~nm}$ using $1 \mathrm{~cm}$ cells.

\section{RESULTS AND DISCUSSION}

Absorption spectra: Fig. 2 shows the absorption spectra of each component. Lead(II) and CPApA blue complex was formed according to standard procedure. The absorbance measurement was firstly made using reagent blank against water (Fig. 2a) and then the complex absorbance of lead against reagent blank (Fig. 2b) was determined and the maximum absorbance at $606 \mathrm{~nm}$ wavelength was obtained. Therefore, in this study $\lambda=606 \mathrm{~nm}$ was selected as the determination wavelength.

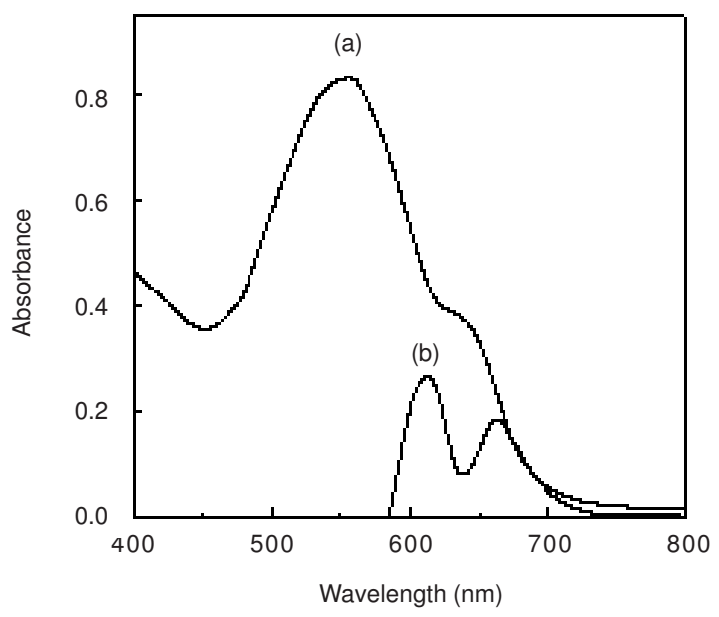

Fig. 2. Absorption spectra (a): reagent blank against water; (b): complex against reagent blank; $\left[\mathrm{Pb}^{2+}\right]=1.45 \times 10^{-5} \mathrm{~mol} \mathrm{~L}^{-1} ;[\mathrm{CPA} p \mathrm{~A}]=4 \times$ $10^{-5} \mathrm{~mol} \mathrm{~L}^{-1} ; \mathrm{pH}=3.5$

Effect of pH: The experiments at $\mathrm{pH} 1.81,2.5,3.0,3.2$, $3.5,3.8,4.1,4.5$ were respectively tested. The results showed that the absorbance was maximum and has not significant change between $\mathrm{pH} 3.2$ - 4.1. Therefore, $\mathrm{pH} 3.5 \mathrm{CH}_{3} \mathrm{COOH}-$ $\mathrm{CH}_{3} \mathrm{COONa}$ was selected as the buffer solution. When the amount of buffer solution was in $0.5-1.5 \mathrm{~mL}$, the absorbance was stable. Thus, in this experiment $1 \mathrm{~mL}$ of buffer solution was chosen.

Effect on amount of $p$-acetylchlorophosphonazo: Under the other conditions being unchanged, CPA $p \mathrm{~A}$ amount effect experiments were made. $0,0.5,1.5,2.5,3.0,3.5,4.0,4.5 \mathrm{~mL}$ of $1 \times 10^{-4} \mathrm{~mol} \mathrm{~L}^{-1} \mathrm{CPA} p \mathrm{~A}$ solutions were respectively added and compared with the reagent blank. Results showed that the amount of CPApA ranged from 0 to $4.0 \mathrm{~mL}$, the absorbance increased with increase in the amount of CPA $p \mathrm{~A}$. When DBCASA dosage was more than $4 \mathrm{~mL}$, the absorbance decreased to smaller extent. The absorbance changed a little over the range of 3.5-4.5 mL and was maximum at $4 \mathrm{~mL}$, thus $4 \mathrm{~mL}$ of $1 \times 10^{-4} \mathrm{~mol} \mathrm{~L}^{-1} \mathrm{CPA} p \mathrm{~A}$ solution was selected.

Effect of order of added reagent on system: Changing the addition order of each reagent in this system, it was found that the order of reagents has not influence on the experimental results of this system.

Stability of system: The measurement experiment of stability of the system was carried out under optimal conditions. When $3 \mu \mathrm{g} \mathrm{mL} \mathrm{m}^{-1}$ of $\mathrm{Pb}^{2+}$ was determined, the absorbance remained invariable after various reagents were added for 10 min. The change of absorbance was less than $5 \%$ within $2.5 \mathrm{~h}$ and the system remained stable.

Composition of complex: The complex formed by $\mathrm{CPA} p \mathrm{~A}$ and $\mathrm{Pb}^{2+}$ presented blue. The ratio of $\mathrm{Pb}(\mathrm{II})$ to $\mathrm{CPA} p \mathrm{~A}$ was $1: 2$, which was measured by molar ratio method and equimolar continuous variation method.

Working curve: Linear range experiment was carried out under optimal conditions. The results showed that when lead(II) content was $0.1-4 \mu \mathrm{g} \mathrm{mL} \mathrm{m}^{-1}$, lead content showed a good linear relationship with $\mathrm{A}$ and the linear regression equation was: absorbance $=0.0088 \mathrm{C}\left(\mathrm{C}: \mu \mathrm{g} \mathrm{mL} \mathrm{mL}^{-1}\right)+0.0172$. The apparent molar absorption coefficient of the method was $\varepsilon_{606 \mathrm{~nm}}=2.56 \times 10^{4} \mathrm{~L} \mathrm{~mol}^{-1} \mathrm{~cm}^{-1}$. Reagent blank was determined 11 times and the relative standard deviation obtained was $1.31 \%$. The detection limit was $0.297 \mu \mathrm{g} \mathrm{mL}^{-1}$ by calculation from the formula $3 \mathrm{~S} / \mathrm{K}$ (S refers to the standard deviation of 11 experiments; K refers to the slope of working curve).

Method selectivity: Co-existing ions effect experiment was carried out under optimal conditions. When $30 \mu \mathrm{g} \mathrm{Pb}{ }^{2+}$ in $10 \mathrm{~mL}$ volume was measured and the relative error was controlled within $\pm 5 \%$, the allowable amount of co-existing ions $(\mu \mathrm{g})$ was as follows: $\mathrm{SO}_{4}{ }^{2-}(6000) ; \mathrm{Br}^{-}(3000) ; \mathrm{Si}^{4+}(1800) ; \mathrm{F}^{-}$ (1500), $\mathrm{I}^{-}$(1500), ascorbic acid (1500); $\mathrm{Ag}^{+}$(900); glucose (300); $\mathrm{NO}_{2}^{--}$(180); $\mathrm{Cl}^{-}(150), \mathrm{CO}_{3}{ }^{2-}(150) ; \mathrm{Hg}^{2+}(30)$, human serum albumin (30); $\mathrm{Cd}^{2+}(15), \mathrm{Zn}^{2+}(15), \mathrm{Sr}^{2+}(15), \mathrm{V}^{5+}(15)$; $\mathrm{W}^{6+}(6), \mathrm{Mo}^{6+}(6), \mathrm{PO}_{4}^{3-}(6) ; \mathrm{Ba}^{2+}(3), \mathrm{Zr}^{4+}(3), \mathrm{Mg}^{2+}(3), \mathrm{Mn}^{2+}$ (3), $\mathrm{Fe}^{3+}(3), \mathrm{Sn}^{4+}(3)$, citric acid (3), oxalic acid (3); $\mathrm{Ni}^{2+}(1.5)$, $\mathrm{Th}^{4+}(1.5) ; \mathrm{Cu}^{2+}(0.6), \mathrm{Cr}^{3+}(0.6), \mathrm{Ti}^{4+}(0.6) ; \mathrm{Ca}^{2+}(0.3), \mathrm{Bi}^{3+}(0.3)$, $\mathrm{Fe}^{2+}(0.3), \mathrm{Al}^{3+}(0.3), \mathrm{S}^{2-}(0.3) ; \mathrm{Hf}^{4+}(0.03)$.

Sample analysis: The potatoes washed and cut into strips and put in an oven of $110{ }^{\circ} \mathrm{C}$ for constant temperature drying for $4 \mathrm{~h}$. An appropriate amount of dried sample was accurately weighed and placed in a ceramic crucible and they were put into a muffle furnace at $650^{\circ} \mathrm{C}$ to be incinerated for $8 \mathrm{~h}$. After the cineration was complete and the sample was taken out for cooling to room temperature. Water was added to make the sample moist and then along the wall $5 \mathrm{~mL}$ of $6 \mathrm{~mol} \mathrm{~L}^{-1}$ hydrochloric acid solution were added to dissolve the residue. The mixture was heated to a near dryness and dissolved with water and transferred to a $10 \mathrm{~mL}$ volumetric flask. Water was used to dilute it to the mark. $1 \mathrm{~mL}$ of test olution was accurately taken and then the determination of lead was made according to the standard procedure. The results are seen in Table- 1 .

\section{Conclusion}

The colour reaction between $\mathrm{Pb}(\mathrm{II})$ and $p$-acetylchlorophosphonazo formed the blue complex. At $\lambda_{\max }=606 \mathrm{~nm}$, the amount of lead(II) in 0.1-4.0 $\mu \mathrm{g} \mathrm{mL}^{-1}$ and absorbance obeyed 


\begin{tabular}{|c|c|c|c|c|c|c|c|}
\hline \multicolumn{8}{|c|}{$\begin{array}{c}\text { TABLE-1 } \\
\text { ANALYTICAL RESULTS OF SAMPLES }\end{array}$} \\
\hline Sample & Found $(\mathrm{n}=13)\left(\mu \mathrm{g} \mathrm{g}^{-1}\right)$ & $\begin{array}{l}\text { Average } \\
\left(\mu \mathrm{g} \mathrm{g}^{-1}\right)\end{array}$ & $\begin{array}{c}\text { Relative } \\
\text { standard } \\
\text { deviation } \\
(\%)\end{array}$ & $\begin{array}{l}\text { Added } \\
\left(\mu \mathrm{g} \mathrm{mL} L^{-1}\right)\end{array}$ & $\begin{array}{l}\text { Recovered } \\
\left(\mu \mathrm{g} \mathrm{mL} L^{-1}\right)\end{array}$ & $\begin{array}{l}\text { Recovery } \\
\quad(\%)\end{array}$ & $\begin{array}{l}\text { Atomicn absor- } \\
\text { ption spectro- } \\
\text { metric contrast } \\
\text { method }\left(\mu \mathrm{g} \mathrm{g}^{-1}\right)\end{array}$ \\
\hline No. 1 & $\begin{array}{l}0.311,0.294,0.277,0.289,0.306,0.294,0.317 \\
0.351,0.294,0.328,0.311,0.300,0.317\end{array}$ & 0.315 & 2.05 & 0.600 & 0.630 & 105.0 & 0.315 \\
\hline No. 2 & $\begin{array}{l}0.102,0.137,0.117,0.117,0.120,0.137,0.117 \text {, } \\
0.137,0.102,0.117,0.102,0.120,0.117\end{array}$ & 0.119 & 1.05 & 1.000 & 0.991 & 99.1 & 0.117 \\
\hline
\end{tabular}

Beer's law. The apparent molar absorption coefficient of the method was $\varepsilon_{606 \mathrm{~nm}}=2.56 \times 10^{4} \mathrm{~L} \mathrm{~mol}^{-1} \mathrm{~cm}^{-1}$ and detection limit was $0.297 \mu \mathrm{g} \mathrm{mL^{-1 }}$. It has satisfactorily been used to determine lead content in potato samples.

\section{REFERENCES}

1. N. Jin and W.Z. Yin, Non-ferrous MiningMetal, 22, 114 (2006).

2. J.H. He, Q. Xu and Z.R. Song, Metal. Anal., 30, 34 (2010).

3. Z.Y. Guo, J. Peng and Y.Q. Fan, Chem. Anal. Meterage, 19, 79 (2010)

4. J. Chen, B.L. Lu, J. Zheng and L. Lin, Phys. Test. Chem. Anal., Part B: Chem. Anal., 45, 1401 (2009).
5. W.Q. Li, S.Y. Shan and H. Zhu, Phys. Test. Chem. Anal., Part B: Chem. Anal., 45, 1417, 1421 (2009).

6. Y. Shan, X.Y. Yang, S.F. He, M. Xiong and C.X. Liu, Chin. J. Spectrosc. Lab., 26, 1531 (2009).

7. Z.Y. Li, Food Sci., 23, 93 (2002).

8. T.P. Hao, H.L. Li, Z.X. Qi, C.M. Sun and C.M. Ma, Metal. Anal., 12, 48 (1992).

9. M.S. Yang, S. Wang and G.L. Chen, Rock Miner. Anal., 14, 292 (1995).

10. J.M. Pan, Z.J. Li, Q.Y. Zhang and G.Z. Fang, New Chromogenic Reagents and Their Application in Spectrophotometry. Beijing: Chemical Industry Publishing House, pp. 34-35 (2003). 